\title{
Edyta Pietrzak*
}

iD https://orcid.org/0000-0003-1878-7545

\section{EDUKACJA DO RÓWNOŚCI I RÓŻNORODNOŚCI NA POLSKICH UCZELNIACH TECHNICZNYCH}

\begin{abstract}
Abstrakt. Potrzeba włączania perspektywy równości i różnorodności do badań naukowych i programów kształcenia wykracza poza nauki społeczne czy humanistyczne i odnosi się także do nauk technicznych kształcenia inżynieryjnego. Jak polskie uczelnie techniczne radzą sobie z tym wymogiem? Czy jest w ich działalności miejsce na uświadamianie studentom wagi kompetencji społecznych? Spróbujmy zatem odpowiedzieć na pytania o miejsce równości i różnorodności w misjach uczelni, badaniach naukowych, programach kształcenia oraz projektach społecznych i edukacyjnych realizowanych na politechnikach, odnosząc się przy tym do światowych dobrych praktyk w tym obszarze.
\end{abstract}

Słowa kluczowe: równość, różnorodność, edukacja, uczelnie techniczne.

\section{Wstęp}

Potrzeba włączania perspektywy równości i różnorodności do badań naukowych i programów kształcenia wykracza poza nauki społeczne i humanistyczne i odnosi się także do nauk technicznych kształcenia inżynieryjnego. Jak polskie uczelnie techniczne radzą sobie z potrzebą włączania tych zagadnień? Spróbujmy odpowiedzieć na pytania o miejsce równości i różnorodności na politechnikach. Określenie owego miejsca w misjach uczelni, badaniach naukowych, programach kształcenia oraz projektach społecznych i edukacyjnych to bardzo ambitne zadanie i projekt mogący wystarczyć na wiele lat pracy badawczej. Toteż celem tego artykułu może być jedynie nakreślenie ich zarysu oraz zaprezentowanie zbioru refleksji mogących zainspirować do dalszych badań.

Na początek pojawia się w związku z tym szereg pytań, których autorka poniższego tekstu spróbuje „dotknąć”. A mianowicie: Skąd wynika potrzeba edukacji do równości i różnorodności? Jak z edukacją prorównościową radzą sobie uczelnie zagraniczne? Czy na polskich uczelniach technicznych jest miejsce na

* Dr hab., Zakład Nauk Humanistycznych, Instytut Nauk Społecznych i Zarządzania Technologiami, Politechnika Łódzka, ul. Wólczańska 215, 93-005 Łódź, e-mail: edyta.pietrzak@p.lodz.pl 
uświadamianie studentom wagi kompetencji społecznych? Czy w programach kształcenia i badaniach naukowych pojawiają się tematy związane $\mathrm{z}$ równością i różnorodnością? Wziąwszy je pod uwagę, można postawić hipotezę, iż ze względu na specyfikę kształcenia i swoisty konserwatyzm panujący w obszarze nauk technicznych i ścisłych, na polskich uczelniach technicznych edukacja do równości i różnorodności oficjalnie nie istnieje, a jeśli mówi się o niej „nie wprost”, to usytuowana jest ona na marginesach prowadzonych tam badań i oferowanych programów kształcenia.

Do badań własnych wykorzystane zostały metody ogólne, poznawcze i teoretyczne, wzbogacone również o metody empiryczne w postaci obserwacji uczestniczącej autorki zatrudnionej na uczelni technicznej i prowadzącej w tejże uczelni zajęcia z nauk społecznych. Owe praktyczne doświadczenia stały się zresztą impulsem do napisania tego tekstu.

Strukturę artykułu tworzą cztery części odwołujące się do postawionych powyżej pytań badawczych. Pierwsza z nich koncentruje się na potrzebie edukacji do równości i różnorodności. Druga odnosi się do dobrych praktyk stosowanych na świecie, gdzie takie kształcenie jest realizowane. Część trzecia poświęcona jest sytuacji na polskich uczelniach technicznych i podejmuje temat jednostek naukowo-dydaktycznych oraz przedmiotów humanistyczno-społecznych na nich wykładanych. Część czwarta odnosi się do pozadydaktycznych działań o charakterze równościowym, które możemy zaobserwować na uczelniach technicznych w postaci akcji promocyjnych, konferencji naukowych oraz programów antydyskryminacyjnych i antymobbingowych.

\section{O potrzebie edukacji do równości i różnorodności}

Edukacja do równości, nazywana także edukacją antydyskryminacyjną, koncentruje się na przekazywaniu wiedzy i działaniach mających na celu wspieranie równości oraz przeciwdziałanie dyskryminacji i wykluczeniu. Oparta jest na wierze w przyrodzoną godność, podmiotowość oraz równość wszystkich ludzi, bez względu na pochodzenie etniczne, narodowe, rasę, sprawność fizyczną, wiek, płeć, orientację seksualną, wyznanie, status społeczny i ekonomiczny (Edukacja antydyskryminacyjna $i$ jej standardy jakościowe 2011). Buduje kompetencje do przeciwdziałania dyskryminacji i rozwija wiedzę na temat wykluczonych, ale także odpowiedzialność społeczną i osobistą. Odwołuje się także do szeroko pojętych praw człowieka i w znacznym stopniu koncentruje na równości płci i prawach kobiet, dlatego też czerpie z dorobku gender studies, czyli studiów nad społeczno-kulturową tożsamością płci. Powstające w ich obszarze analizy odwołują się do perspektywy interdyscyplinarnej i niejednokrotnie łączą dorobek antropologii, psychologii, socjologii, literaturoznawstwa, teorii sztuki, lingwistyki czy historiografii (Encyklopedia gender 2014). Mają najczęściej charakter krytyczny oraz 
zwracają uwagę na stereotypy i nierówności w obszarze ról społecznych pełnionych przez kobiety i mężczyzn, a tym samym wskazują podział na płeć biologiczną i społeczno-kulturową. Odnoszą się zatem wprost do praktyk marginalizacji, którym edukacja równościowa ma zapobiegać i przeciwdziałać.

Bliska równości tematyka różnorodności podejmowana jest przez przedstawicieli nauk humanistycznych i społecznych, ale też ścisłych, przyrodniczych czy technicznych już nie tylko w perspektywie edukacji, lecz również w rozważaniach teoretycznych, badaniach empirycznych oraz w praktyce biznesowej. Łączona jest ze społeczną odpowiedzialnością przedsiębiorstw (Corporate Social Responsibility - CSR) oraz etyką biznesu (Adamczyk 2009; Freeman 2010; Grosser 2009; Jastrzębska 2016). Jednocześnie, ze względu na mnogość zawartych w tym obszarze pojęć, jest to także obszar nie do końca rozumiany i wzbudzający duże emocje. Sprawia często kłopoty zarówno definicyjne, jak i interpretacyjne (Anand, Winters 2008)

W Polsce oprócz socjologicznych badań nad wykluczeniem i marginalizacją (Szarfenberg 2006; Galor 2009), badań z zakresu polityki społecznej (Sałustowicz 2009; 2014), analiz feministycznych poświęconych dyskryminacji ze względu na płeć (Desperak 2013), czy nauk o kulturze, tematyka różnorodności podejmowana jest $\mathrm{w}$ dyscyplinie nauk pedagogicznych (Chmura-Rutkowska 2016) oraz nauk o zarządzaniu. Zarządzanie różnorodnością oznacza dostrzeganie różnic między ludźmi i świadome rozwijanie strategii, polityk i programów, które tworzą klimat dla ich poszanowania i wykorzystania. Jego celem jest stworzenie takiego środowiska, w którym każda osoba czuje się szanowana i doceniana i w którym może w pełni realizować swój potencjał, co przyczynia się jednocześnie do sukcesu organizacji (Bombiak 2014). A zatem różnica, która jest nieodłącznym elementem organizacji, nie jest traktowana tu jako deficyt, lecz jako potencjał (Zaroda-Dąbrowska 2015).

Co istotne, wszelkie przejawy różnorodności, takie jak: płeć, wiek, pochodzenie etniczne, wyznanie, sprawność fizyczna, status społeczny czy orientacja seksualna, w tradycyjnych społeczeństwach funkcjonowały na marginesach sfery publicznej i stanowiły podstawę do wykluczenia. W dzisiejszym świecie obserwujemy globalny proces przesunięcia reprezentantów różnorodności z peryferii sceny politycznej do jej centrum oraz rosnącą siłę głosu marginalizowanych dotąd mniejszości. Ze względu na zmianę warunków funkcjonowania sfery publicznej, a mianowicie: procesy globalizacyjne, powszechność edukacji czy wzmożoną aktywność migracyjną, zaobserwować można, iż reprezentanci grup pozostających dotychczas na obrzeżach sfery publicznej relokują swoją aktywność do jej centrum, zmieniając tym samym dynamikę procesów i systemów społeczno-politycznych. W związku z tym rzeczowa analiza zjawiska różnorodności, będąca punktem wyjścia do wypracowania zasad i procedur wspólnego funkcjonowania w sferze publicznej i jej uznanie są punktem wyjścia prowadzącym do tworzenia szczegółowych polityk na poziomie rynku pracy, szkolnictwa, ochrony zdrowia (Sztobryn-Giercuszkiewicz 2016) czy świadczeń społecznych. 
Podejmowanie tematu różnorodności społecznej w edukacji jest niezbędne. $\mathrm{Z}$ różnorodnością spotykamy się bowiem na co dzień w środowisku organizacji międzynarodowych, transnarodowych korporacji i ludzkich relacji, zarówno w aspekcie kultury, religii, różnic etnicznych, płciowych, wieku, światopoglądu czy preferencji dotyczących stylu życia i musimy umieć sobie z nią radzić. Co więcej, edukacja do równości może pomóc w zapobieganiu ksenofobii, rasizmowi i populizmom, z którymi zmaga się współczesny świat.

\section{Dobre praktyki w edukacji równościowej, czyli jak to robią na świecie?}

Wiodące uczelnie techniczne świata rozwijają strategie w zakresie promowania równości i różnorodności w badaniach i instytutach badawczych. Dobrymi przykładami w tym względzie są np. działania podejmowane przez Massachusetts Institute of Technology (MIT), który w misji uczelni posiada zapisy o konieczności uświadamiania studentom wagi równości, promowaniu kwestii gender i intersekcjonalności oraz łączeniu gender z elementami tożsamości, etnicznością, klasą społeczną, afiliacją religijną. Proponowane przez MIT kursy i programy, jak np. program Women's and Gender Studies (WGS) ${ }^{1}$, obejmują przekazywanie wiedzy o organizacji społeczeństwa, wartościach kulturowych, tworzą sieci łączące pracowników i studentów, wspomagają integrację mniejszości, wzmacniają kampusową społeczność ${ }^{2}$. Program działa już ponad trzydzieści lat i jego celem jest edukacja studentów MIT w zakresie znaczenia równości płci oraz jej związków z rasą, pochodzeniem etnicznym, klasą, zdolnościami, przynależnością religijną i innymi kategoriami tożsamościowymi. Program WGS opiera się na interdyscyplinarnej ścieżce studiów licencjackich, zapewniając społeczności studentów, wykładowców i pracowników udział w badaniach naukowych koncentrujących się na zagadnieniach dotyczących kobiet i płci. Odgrywa on również ważną rolę w projektach ułatwiających dyskusję na temat płci i problemów kobiet wśród studentek i studentów, pracowników, pracownic i szerszej społeczności MIT. W różnych aspektach swojej misji edukacyjnej, czy to poprzez nauczanie, badania czy programowanie,

\footnotetext{
${ }^{1}$ Massachusetts Institute of Technology Program in Women's and Gender Studies, http://wgs. mit.edu/

${ }^{2}$ Kursy oferowane w ramach programu w roku 2018 to: Wprowadzenie do badań nad kobietami i płcią; Kobiety i globalny aktywizm w mediach i polityce; Badania nad płcią i mediami; Rasa i tożsamość w literaturze amerykańskiej; Czarna sprawa. Wprowadzenie do czarnych studiów; Płeć, medycyna i zdrowie publiczne; Rasa, kultura i płeć w USA i za granicą; Perspektywa psychologiczna; Tożsamości i skrzyżowania; Literatury queer; Rasa, płeć i nierówności społeczne; Opieka zdrowotna w zakresie reprodukcji w Stanach Zjednoczonych; Obrazy Azjatyckich Kobiet. Smocze Panie i kwiaty lotosu; Myśl feministyczna; Płeć: Perspektywy historyczne; Płeć, rasa i sprawiedliwość ekologiczna.
} 
WGS stara się wspierać wysiłki MIT na rzecz promowania społecznej sprawiedliwości, integracji i różnorodności, jednocześnie kształcąc kolejne pokolenia liderów do działania w coraz bardziej zróżnicowanych miejscach pracy.

WGS prowadzi obecnie dwie interdyscyplinarne grupy badawcze: The Borders Research Initiative ${ }^{3}$ i Gender and Technology Initiative, oraz należy do (działającego od roku 1993) The Graduate Consortium in Women's Studies, zawiązanego przez MIT i inne uczelnie z rejonu Bostonu: Harvard University, Boston College, Brandeis University, Tufts University, Northeastern University, Boston University, Simmons College. Filie programu WGS mieszczą się w licznych jednostkach naukowo-badawczych, w tym w: Antropologii, Literatury, Historii, Nauk Politycznych, Lingwistyki i Filozofii, Architektury, Studiów Globalnych i Języków, Studiów/Pisarstwa Porównawczego, Mediów oraz Studiów Nauki, Technologii i Społeczeństwa (STS).

Podobne działania prowadzi Georgia Institute of Technology w Atlancie, gdzie na kursach genderowych analizuje się kwestie obywatelskie, sposoby i wyniki głosowania, stereotypy itp. The Center for the Study of Women, Science and Technology (WST) w ramach Georgia Tech ${ }^{4}$ promuje rekrutację, zatrudnianie i awanse kobiet na wydziałach nauk ścisłych, technologii, inżynierii i matematyki (STEM). Program Georgia Tech Women in Engineering (WIE) ${ }^{5}$ jest poświęcony rekrutowaniu najlepszych studentek na kierunki inżynieryjne, a po ich zapisaniu się na studia, ma na celu zapewnić im wsparcie środowiska i zachęcać do przejawiania ciekawości, kreatywności oraz rozwoju intelektualnego i osobistego. WIE dąży do ponownego zdefiniowania zawodu inżyniera jako pozytywnej siły społecznej posiadającej potencjał do poprawy jakości życia poprzez tworzenie technologii zmieniających świat.

$\mathrm{Na}$ Uniwersytecie Stanforda powstał prowadzony przez prof. Londę Schiebinger projekt Gender Innovations (GI) ${ }^{6}$, obejmujący nauki ścisłe, medycynę, nauki inżynieryjne oraz ochronę środowiska. Od 2011 roku projekt realizowany jest wspólnie z Unią Europejską, od 2013 z US National Science Foundation. Pracują przy nim eksperci i ekspertki z USA, Kanady, UE oraz krajów azjatyckich. Jego celem jest wspomaganie badań naukowych i inżynierskich w celu zapewnienia wysokiej jakości wyników pracy, wspomaganie społeczeństwa przez kierowanie badaniami tak, by odpowiadały społecznym potrzebom, oraz wspomaganie biznesu, rozwijanie nowych idei, patentów, technologii. Program stymuluje genderową wrażliwość, odpowiedzialność nauki i technologii oraz promuje strategie w zakresie zwiększenia liczby kobiet $\mathrm{w}$ badaniach i promowania równości w instytutach badawczych (Hyży 2017: 148).

\footnotetext{
3 The Borders Research Initiative, http://bri.mit.edu/

${ }^{4}$ Centre for the Study of Women, Science and Technology (WST), https://wst.gatech.edu/

${ }^{5}$ Georgia Tech Women in Engineering (WIE), https://wie.gatech.edu/

${ }^{6}$ Gender Innovations (GI), https://genderedinnovations.stanford.edu/
} 


\section{Miejsce edukacji równościowej na polskich uczelniach technicznych}

Na polskich uczelniach technicznych dostrzegana jest potrzeba wzbogacenia kształcenia inżynieryjnego o wiedzę rozwijającą kompetencje społeczne, współpracę i komunikację (S ośnicka 2017: 5). To one wpływają na niezbędną i oczekiwaną innowacyjność. Studenci za realizację zajęć z przedmiotów humanistyczno-społecznych w toku kształcenia otrzymują 5 pkt ECTS.

Kształcenie w zakresie nauk humanistycznych i społecznych na uczelniach technicznych może odbywać się w trzech formach. Po pierwsze, znaleźć możemy na nich wydziały społeczne lub humanistyczne, np. Wydział Humanistyczny Akademii Górniczo-Hutniczej, Wydział Humanistyczny Politechniki Koszalińskiej czy Wydział Administracji i Nauk Społecznych Politechniki Warszawskiej. Po drugie, tego typu kształcenie podejmowane jest także przez instytuty i katedry w ramach wydziałów, np. Instytut Nauk Społecznych i Zarządzania Technologiami, a w nim Zakład Nauk Humanistycznych na Wydziale Zarządzania i Inżynierii Produkcji Politechniki Łódzkiej, Katedra Nauk Społecznych i Filozoficznych, Zakład Nauk Społecznych i Zakład Nauk Filozoficznych na Wydziale Zarządzania i Ekonomii Politechniki Gdańskiej czy Katedra Nauk Humanistycznych Politechniki Rzeszowskiej. Oprócz tego możemy na uczelniach technicznych znaleźć niezależne studia lub centra specjalizujące się w naukach humanistycznych i społecznych ${ }^{7}$. Jednym z nich jest Studium Nauk Humanistycznych i Społecznych Politechniki Wrocławskiej - ogólnouczelniana jednostka naukowo-dydaktyczna o charakterze wielodyscyplinarnym, prowadząca zarówno badania naukowe w zakresie niektórych nauk podstawowych, jak i badania o charakterze utylitarnym, mające znaczenie dla rozwoju dydaktyki przedmiotów humanistycznych i pedagogicznych w uczelniach technicznych, oraz dydaktykę przedmiotów humanistycznych, społecznych i pedagogicznych na wszystkich typach kierunków studiów w Politechnice Wrocławskiej ${ }^{8}$.

Oferta dydaktyczna dla studentów uczelni technicznych w ramach zajęć humanistyczno-społecznych jest bardzo bogata i zróżnicowana, zawiera zajęcia z: psychologii, komunikacji społecznej, socjologii, etyki, prawa, ale też np. antropologii przestrzeni, psychologii miast czy antropologii odżywiania9. Ostatnio

${ }^{7}$ Wymienione jednostki stanowią tylko przykłady mogące stanowić przyczynek do dalszych pogłębionych badań i analizy oferty dydaktycznej polskich uczelni technicznych.

${ }^{8}$ Studium Nauk Humanistycznych i Społecznych Politechniki Wrocławskiej, http://snhis. pwr.edu.pl/

9 Przykładowe kursy w ramach kształcenia humanistyczno-społecznego dla studentów uczelni technicznych w Polsce są oferowane najczęściej w formie przedmiotów do wyboru i dotyczą oferty dla różnych kierunków i specjalności:

Człowiek i technika; Antropologiczne aspekty rozwoju techniki; Efektywna komunikacja; Efektywne zarządzanie czasem; Ergonomia i bezpieczeństwo pracy; Estetyka przestrzeni z elementami socjologii miasta i urbanizacji; Etyczne aspekty w biotechnologii; 
najczęściej powoływane i dopasowywane są one do potrzeb konkretnych kierunków studiów i specjalności.

Brakuje natomiast w ofercie dydaktycznej kursów humanistyczno-społecznych na polskich uczelniach technicznych propozycji o jednoznacznie równościowym czy różnorodnościowym charakterze. Wątki genderowe mogą jednakże znajdować się w programach kursów dedykowanych innym zagadnieniom, np. na socjologii, psychologii, ale też na zarządzaniu przy okazji zarządzania różnorodnością.

\section{Pozadydaktyczne dzialania o charakterze równościowym}

Najbardziej znanym przykładem akcji promujących równość na uczelniach technicznych jest program „Dziewczyny na politechniki”, zainicjowany przez Konferencję Rektorów Polskich Uczelni Technicznych i realizowany przez Fundację Edukacyjną Perspektywy w 2006 roku. Dodatkowo wspierany jest on także przez programy: „Dziewczyny do ścisłych”, „IT for SHE”, „Nowe technologie dla dziewczyn", realizowane przez Fundację Intel-Perspektywy. Wszystkie te programy przynoszą efekty.

Etyka; Etyka inżynierska; Etyka nowych technologii; Etyka środowiskowa; Etyka w biznesie;

Filozofia; Filozofia informacji; Filozofia nauki i techniki; Filozofia społeczna; Filozofia techniki i estetyka nowych technologii; Filozoficzne problemy współczesnego świata;

Humanistyczne aspekty rozwoju zrównoważonego; Humanistyka i technologie; Ja pośród innych;

Komunikacja interpersonalna; Komunikacja społeczna; Komunikacja społeczna - cywilizacje - organizacje - media; Komunikacja społeczna - medioznawstwo i teorie komunikowania; Komunikacja społeczna - teorie mediów i poznania;

Kultura i etyka zachowań w biznesie;

Metodologia pracy doświadczalnej; Metody autoprezentacji;

Nauka i technologie; Współczesne zagadnienia z filozofii fizyki i matematyki; Ochrona własności intelektualnej;

Podstawy filozofii i etyki w biznesie; Podstawy negocjacji;

Polska we współczesnej Europie;

Praktyczna komunikacja międzyludzka;

Prawne i etyczne aspekty pracy inżyniera; Prawo i etyka w nauce i dydaktyce; Prawo własności intelektualnej;

Propedeutyka kariery zawodowej; Propedeutyka pracy naukowej; Przygotowanie do twórczej drogi zawodowej;

Psychologia negocjacji i kierowanie zespołem; Psychologia architektury i estetyka krajobrazu; Psychologia relacji międzyludzkich; Psychologia transportu; Retoryka i techniki prezentacji;

Socjologia; Socjologia organizacji i kierowania; Socjologia przestrzeni: Miasto i obszary wiejskie; Socjologia. Teoria społeczeństwa i polityki; Sztuka wystąpień publicznych;

Technologiczne transformacje społeczeństwa; Technologie w cywilizacjach. Zagadnienia z psychologii i pedagogiki międzykulturowej;

Teoria wiedzy; Trening relaksacji - radzenie sobie ze stresem; Trening twórczego myślenia;

Własność intelektualna i prawa autorskie;

Wprowadzenie do filozofii. Wspólnota i odpowiedzialność. 
Podczas organizowanego w ramach kampanii dnia otwartego wykładowczynie, pracujące na uczelniach studentki i absolwentki spotykają się z uczennicami, aby opowiedzieć im o swoich ścieżkach kariery i zawodowych fascynacjach. Zapraszają dziewczyny do zwiedzania laboratoriów, organizują dla nich warsztaty, wykłady i pokazy. Oprócz kampanii w projekcie przygotowywane są coroczne raporty ukazujące stan partycypacji kobiet i dziewcząt w kształceniu na poziomie uczelni technicznych.

Kampania „Dziewczyny na politechniki” to pionierski i największy projekt promujący kierunki techniczne, inżynierskie i ścisłe wśród młodych kobiet w Polsce i w Europie Środkowo-Wschodniej. W ciągu ostatnich 11 lat popularność uczelni technicznych wśród uczennic i udział dziewczyn na politechnikach wzrósł z 31\% do 37\%. W roku akademickim 2017/2018 odnotowano w Polsce największy w historii przyrost liczby studentek kierunków informatycznych - o 1179 w skali kraju (11,6\% więcej niż rok wcześniej). Najwięcej kobiet studiuje na kierunkach technicznych związanych z architekturą, chemią i biotechnologią $-70-80 \%$. Najmniej studentek wybiera kierunki związane z elektrotechniką, mechatroniką, automatyką, mechaniką i budową maszyn $-6-9 \%$.
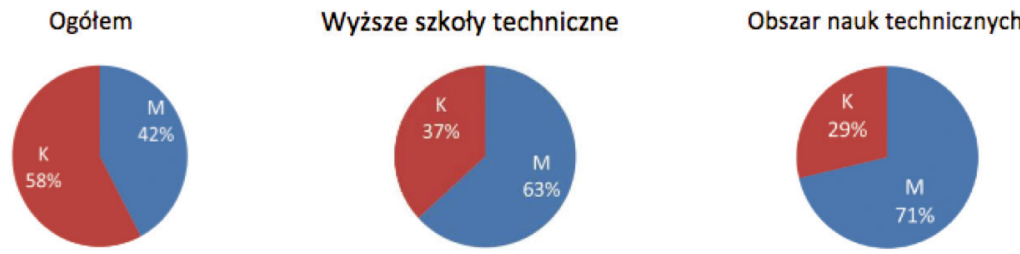

Rysunek 1. Udział kobiet wśród studiujących kierunki techniczne

Źródło: Kobiety na politechnikach. Raport 2018

Doktorantki stanowią obecnie $41 \%$ wszystkich doktorantów wyższych szkół technicznych. W ciągu ostatnich 10 lat udział kobiet wśród doktorantów na uczelniach technicznych wzrósł o prawie 8 pkt procentowych.

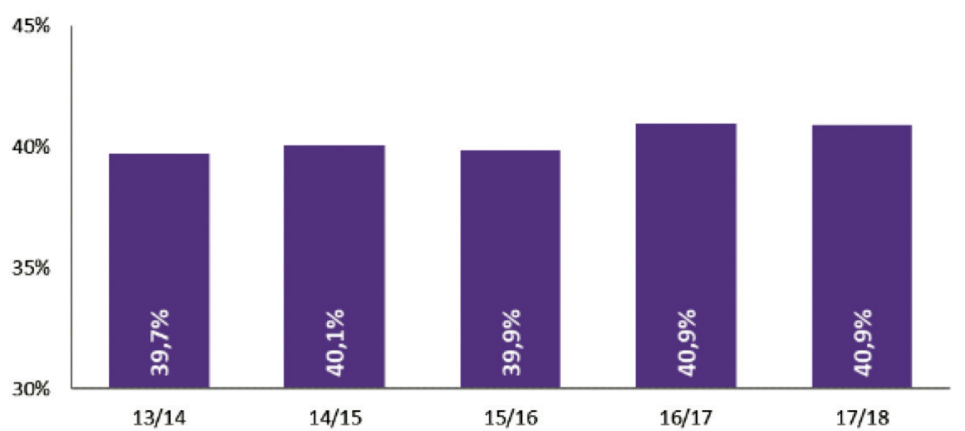

Rysunek 2. Udział kobiet wśród doktorantów wyższych szkół technicznych w latach 2014-2018 
W wyższych szkołach technicznych pracuje $25 \%$ kobiet ze stopniem doktora habilitowanego i $33 \%$ ze stopniem doktora. Kobiet profesorek na uczelniach technicznych jest $14 \%$.
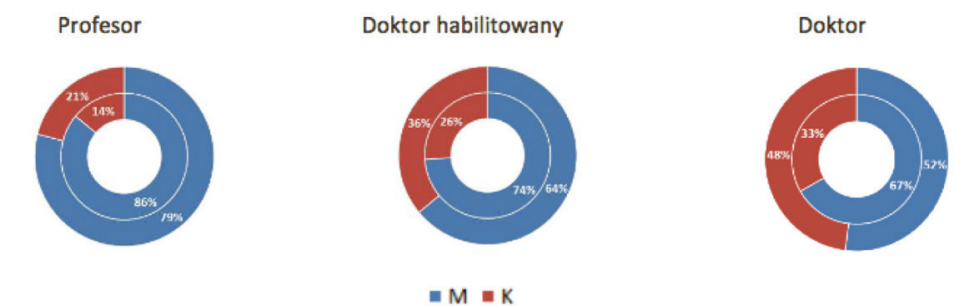

wewnętrzny pierścień - wyższe szkoły techniczne; zewnętrzny pierścień - ogółem szkoły wyższe

Rysunek 3. Kadra naukowa, rok akademicki 2017/2018

Źródło: Kobiety na politechnikach. Raport 2018

Żadna kobieta nie sprawuje obecnie funkcji rektora uczelni technicznej. Wśród 88 prorektorów jest ich tylko 12 (co stanowi 13\%), na 5 mężczyzn dziekanów przypada zaś 1 pani dziekan.

Do innych pozadydaktycznych działań promujących różnorodność i równość na uczelniach technicznych należą konferencje, akcje i programy. W dniach 29-30 września 2016 roku w Łodzi odbyła się pierwsza międzynarodowa konferencja „Women in Science - the Tradition of Maria Skłodowska-Curie”, zorganizowana przez Ministerstwo Nauki i Szkolnictwa Wyższego, Rektora Politechniki Łódzkiej i Polskie Stowarzyszenie Stypendystów Fullbrighta, na której uczone reprezentujące różne obszary nauki miały okazję przedstawić swoje badania i doświadczenia w zakresie funkcjonowania kobiet-badaczek oraz możliwość networkingu. Pojawia się tu jednak pytanie, czy wszystkie konferencje poświęcone kobietom w nauce mają wymiar równościowy? Z pewnością jednak przyczyniają się one do budowania atmosfery równościowej wśród naukowców i naukowczyń oraz dają przestrzeń i prawo głosu grupom dotąd w nauce marginalizowanym.

Do promowania kultury równości i różnorodności przyczyniają się również takie programy jak realizowana na Politechnice Warszawskiej „Polityka przeciwdziałania mobbingowi i dyskryminacji” - promująca rozwiązania prawne zaczerpnięte spoza uczelni oraz standardy UE. Pozostaje jednak zapytać, na ile świadczy to o różnorodności i prorównościowym charakterze uczelni?

$* * *$

Próbując podsumować powyższe rozważania i przykłady dobrych praktyk oraz odwołując się do postawionej na wstępie hipotezy, stwierdzić należy, że na polskich uczelniach technicznych oficjalnie brakuje miejsca na edukację do równości i różnorodności. Przyczyny takiego stanu rzeczy są złożone. Po pierwsze, kształcenie kompetencji społecznych, a do takich należy równość i różnorodność, 
to tylko oferta uzupełniająca i wzbogacająca proces kształcenia na uczelniach technicznych i nie należy do głównego nurtu ich działalności. Po drugie, wspomnieć należy tradycyjne nastawienie przedstawicieli nauk technicznych oraz niewielką liczbę kobiet w nich pracujących, co przyczynia się do powstania swego rodzaju sprzężenia zwrotnego, działającego w tych dyscyplinach. Jeśli kobiet na uczelniach jest mniej, a tematyka równości i różnorodności stosunkowo częściej podejmowana jest $\mathrm{w}$ badaniach właśnie przez kobiety, to ewidentna staje się jej mniejsza obecność. Po trzecie, w kontekście polskim zwrócić należy uwagę także na niedostateczną społeczną wiedzę dotyczącą omawianych obszarów i polityczne negatywne konotacje wiążące się z niezrozumieniem tytułowych kategorii, które z pewnością nie zachęcają do poważnych badań w tym względzie.

$\mathrm{W}$ takiej sytuacji tym bardziej należy więc zachęcać do podejmowania tego tematu. Potencjalne genderowe badania naukowe na uczelniach technicznych wykorzystane mogą być bowiem w projektach interdyscyplinarnych i transdycyplinarnych oraz przyczynić się do rozwijania innowacyjnych gałęzi nauki. Badania z zakresu równości i różnorodności wspomagają studia i prace inżynierskie w zapewnieniu wysokiej jakości wyników pracy. Badacze i badaczki wspomagają także społeczeństwo przez kierowanie badaniami, tak by odpowiadały społecznym potrzebom. I wreszcie, wspomagają biznes w rozwijaniu nowych idei, patentów, technologii.

Przyznać należy, że pośród największych wyzwań, przed jakimi stajemy dziś jako ludzkość, problemy odnoszące się wprost do różnorodności, takie jak ubóstwo, bezrobocie oraz katastrofy społeczne i ekonomiczne, zajmują czołowe miejsca (Bauman, Bauman, Kociatkiewicz, Kostera 2017). By móc je rozwiązać, potrzebujemy nie tylko innowacji technologicznych, ale i społecznych, wynikających z głębokiego humanistycznego namysłu, który pomoże konstruktywnie pokonać czas interregnum, w którym przyszło nam żyć.

\section{Bibliografia}

Adamczyk Jadwiga (2009), Społeczna odpowiedzialność przedsiębiorstw: Teoria i praktyka, PWE, Warszawa.

Anand Rohini, Winters Mary-Frances (2008), A Retrospective View of Corporate Diversity Training from 1964 to the Present, „Academy of Management Learning and Education”, nr 7(3), s. $356-372$.

Bauman Zygmunt, Bauman Irena, Kociatkiewicz Janusz, Kostera Monika (2017), Zarządzanie w płynnej nowoczesności, Wydawnictwo Bęc Zmiana, Warszawa.

Bombiak Edyta (2014), Zarządzanie różnorodnościa wyzwaniem dla współczesnych menedżerów, „Zeszyty Naukowe Uniwersytetu Humanistyczno-Przyrodniczego w Siedlcach. Administracja i Zarządzanie", z. 102, s. 109-122.

Chmura-Rutkowska Iwona, Duda Maciej, Mazurek Marta, Sołtysiak-Łuczak Aleksandra (2016), Gender w podręcznikach, Fundacja Feminoteka, Warszawa.

Desperak Izabela (2013), Płeć zmiany. Zjawisko transformacji w Polsce z perspektywy gender, Wydawnictwo Uniwersytetu Łódzkiego, Łódź. 
Edukacja antydyskryminacyjna i jej standardy jakościowe (2011), Towarzystwo Edukacji Antydyskryminacyjnej, Warszawa.

Encyklopedia gender (2014), Wydawnictwo Czarna Owca, Warszawa.

Fraser Nancy, Honneth Axel (2003), Redistribution or Recognition? A Political-Philosophical Exchange, Verso, London-New York.

Friedman Andrew L., Miles Samantha (2006), Stakeholders. Theory and Practice, Oxford University Press, Oxford.

Grosser Kate (2009), Corporate Social Responsibility and Gender Equality: Women as Stakeholders and the European Union Sustainability Strategy, „Business Ethics. A European Review”, nr 18(3), s. 290-307.

Hyży Ewa (2017), Gender i nauki techniczne. Sprawiedliwość, innowacyjność, rzetelność, [w:] Joanna Sośnicka (red.), Inżynier z dusza humanisty, Wydawnictwo Politechniki Łódzkiej, Łódź, s. 133-152.

Jastrzębska Ewa (2016), Zarządzanie różnorodnościa jako element CSR - dobre praktyki i korzyści, „Marketing i Rynek”, nr 8, s. 12-17.

Kobiety na politechnikach. Raport 2018, http://www.dziewczynynapolitechniki.pl/raport [dostęp 14.10.2019].

Kymlicka Will (2007), Multicultural odysseys: Navigating the New International Politics of Diversity, Oxford University Press, Oxford.

Leks-Bujak Ewa (2014), Zarządzanie różnorodnościa w organizacji, „Zeszyty Naukowe Politechniki Śląskiej. Organizacja i Zarządzanie”, z. 72(1918), s. 101-114.

Letki Natalia (2008), Does diversity erode social cohesion? Social capital and race in British neighbourhoods, „Political Studies”, nr 56(1), s. 99-126.

Sałustowicz Piotr (2009), Pomoc społeczna w wybranych krajach Unii Europejskiej, Instytut Rozwoju Służb Publicznych, Warszawa.

Sałustowicz Piotr (2014), Afirmacja czy kontestacja? Dylemat społeczeństwa kapitalistycznego w kryzysie, Societas Pars Mundi, Bielefeld.

Sośnicka Joanna (red.) (2017), Inżynier z duszq humanisty, Wydawnictwo Politechniki Łódzkiej, Łódź.

Szarfenberg Ryszard (2006), Marginalizacja społeczna i wykluczenie. Wykłady, Instytut Polityki Społecznej Uniwersytetu Warszawskiego, Warszawa.

Sztobryn-Giercuszkiewicz Joanna (2016), Alter idem - student z niepetnosprawnościa w systemie szkolnictwa wyższego, [w:] Elżbieta Zakrzewska-Manterys, Jakub Niedbalski (red.), Samodzielni, zaradni, niezależni. Ludzie niepetnosprawni w systemie polityki, pracy i edukacji, Wydawnictwo Uniwersytetu Łódzkiego, Łódź, s. 99-146.

Walzer Michael (1983), Sphers of Justice: A Defence of Pluralism and Equality, Basic Books, New York.

Zaroda-Dąbrowska Anna (2015), Zarządzanie różnorodnościa jako wyzwanie menedżerów. Wykorzystanie potencjału starszych pracowników - case study, [w:] Marek Makowiec (red.), Wybrane problemy $w$ ksztaltowaniu zachowań organizacyjnych, Uniwersytet Ekonomiczny w Krakowie, Kraków, s. 37-44. 


\section{Edyta Pietrzak}

\section{EDUCATION FOR EQUALITY AND DIVERSITY AT POLISH TECHNICAL UNIVERSITIES}

Summary. The need to integrate an equality and diversity perspective into research and education programmes goes beyond social sciences and humanities and also applies to technical sciences in engineering education. How are Polish technical universities dealing with this need? Is there space for making students aware of the importance of social competences? Let us try to answer questions about the place of equality and diversity and the missions of universities, scientific research, educational programmes and social and educational projects carried out at polytechnics, referring to global good practice in this area.

Keywords: equality, diversity, education, technical universities. 